\title{
Exploration of the Effective Ways of Ideological and Political Education for the Post-90s College Students*
}

\author{
Tian Yang \\ School of Mechanical Electronic \& Information \\ Engineering \\ China University of Mining and Technology (Beijing) \\ Beijing, China
}

\author{
Hongzhi Cao \\ School of Mechanical Electronic \& Information \\ Engineering \\ China University of Mining and Technology (Beijing) \\ Beijing, China
}

\begin{abstract}
The paper aimed to integrate the awareness of service and the concept of practice education into the ideological and political education of the post-90s College Students through taking part in volunteer service inside and outside school. Another purpose of this paper is to set up the core idea of people-oriented education and morality education guided by the Marx theory, which will impel post-90s College Students enhancing their comprehensive ability constantly in the process of serving and contributing to society. The paper expounds that using the method of improving mechanisms can further stimulate post-90s College Students' enthusiasm to volunteer service and also can strengthen their recognition of school and social mission. By using this method post-90s College Students can better build consensus and form resultant force. All these benefits above will help the realization of the Chinese dream.
\end{abstract}

Keywords-post-90s college students; ideological and political education; volunteer service

\section{INTRODUCTION}

The post-90s college students are the key forces for the development of the country. They are the principal parts in practicing the core values of Chinese socialism. Therefore, the education of ideological and political for Post-90s College Students is very important and cannot be discounted.

\section{THE IDEOLOGICAL CHARACTERISTICS OF THE POST- 90S COLLEGE STUDENTS}

Today, the economic situation is complex and changeable. The culture also faces the constant impact of the western world. People sometimes are not well prepared to the quickly renew and replacement of information technology. As the rapid changing of the nation's economy and culture mainly began from 1990s, for the students who was born in this period of time their growth environment had also changed a lot. Their ways of life are obviously affected by the external environment. So, the Post-90s College Students have formed some distinctive features as follows.

* Supported by Fundamental Research Funds for the Central Universities in 2017 of CUMTB

\section{A. Consciousness of Individuation Service}

Compared to the college students in 70 s or 80 s, the Post90s College Students are more abundant and fulfilling both in material and spiritual life. Coupled with the impact of the national family planning policy, most of the Post-90s College Students are the only child is much concerned in the family. With the advent of the age of quality education, the education accepted by the Post-90s College Students is biased towards the elite model. Now, most of the parents pay more attention to hear their voices and respect their opinions. This phenomenon leads to the expression and self-realization of some Post-90s College Students in their growth process Some Post-90s College Students can't stand well in others' perspective for others, and lack certain service consciousness.

\section{B. Diversity of Values}

Because of the impact of network culture and a lack of social practice, the value orientation of the Post-90s College Students is also diversified. Since twenty-first Century, Internet technology has achieved great leap forward development. On the one hand, the Internet has brought great convenience to them in all aspects of life and other aspects. On the other hand, the consequent derivatives- "network culture" is quietly forming. But due to the virtual network culture and not subject to geographical restrictions and other characteristics, some non-positive words and ideas with the development of the network to the overwhelming hit 90 students, this is undoubtedly a major test for the 90 students who lack of social experience ${ }^{[1]}$.

According to the survey results of the National College Students' ideological and political situation in 2016: In the evaluation of College Students' quality of their own group civilization, the research group investigated 12 representative indicators comprehensive literacy of their surrounding groups through their dedication, collective sense, discipline and integrity. Calculating by the system, the score of the comprehensive quality of the college students is between 6.62 and 7.62. Among them, the scores of 5 indexes collective concept, power consciousness, dedication spirit, 
discipline concept and diligent and thrifty are the five post countdown ${ }^{[2]}$.

My unit and group are engaged in college students' ideological and political research for many years, with rich work experience and practical data. It can be seen from the management of daily affairs to students: Most of the Post90s College Students have a positive mind, they are more optimistic about the situation of the country, they are concerned about current affairs and politics, they agree with the leadership of the Communist Party of China, and they take the initiative to close the party organization. They actively participate in various stylistic activities. They are good at playing their own strengths in various stylistic activities. They can actively express their thoughts. However, we must not neglect that some bad phenomena such as weak service consciousness, weakening of ideals and beliefs and pluralistic motives of joining the party have bred in the Post90s College Students.

In conclusion, Post-90s College Students have their own characteristics, how to interpret their thoughts with their expertise to carry out the work and give full understanding and trust for them through the problem, how to find effective ways to actively carry out ideological guidance and cultivation of values without delay.

\section{RESEARCH ON THE CARRIER OF IDEOLOGICAL} EDUCATION FOR THE POST-90S COLLEGE STUDENTS

\section{A. The Importance of Colleges and Universities to the Ideological and Political Education of College Students}

On the issue of ideological and political education for Post-90s College Students, as the main position of education, universities have unparalleled advantages. So we should give full play to the role of educational body. In 2016, at the National College Ideological and Political work conference, general secretary Xi Jinping pointed out that the ideological and political work in colleges and universities is related to the fundamental issue of what kind of people to train, how to train people and who to train for people. As the main position of education, colleges and universities should pay attention to the ideological characteristics of Post-90s College Students, follow the growth rule of college Students under the new situation. Colleges and universities should improve the way of ideological and political education of college students, and effectively promote the steady development of Post-90s College Students' Ideological and political education.

The survey of College Students' ideological and political education in the year of 2016 shows that college students are more satisfied with the overall situation of ideological and political education. Among them, $65.7 \%$ of the daily ideological and political education is more satisfied, and the proportion of affirmative evaluation is up to $92.7 \%$. $77.1 \%$ of the students have participated in the "Study Lei Feng" and "Excel in the performances" theme educational activities. About extracurricular social practice, $90.6 \%$ of students said they would like to take part in the activities without affecting their learning life, and their willingness to participate was higher than other daily ideological and political education activities. $89.4 \%$ of college students believe that counselors' daily ideological and political work has a positive effect on their ideological and moral development, of which $59.2 \%$ of college students believe that counselors consider "great function".

\section{B. Ideological and Political Education of College Students Should Pay Attention to the Concept of "People- oriented"}

Under the new historical starting point, to strengthen the ideological and political education for the Post-90s College Students, we must adhere to the implementation of the party's line and policy. We should carry out the nineteen spirit of the party in depth, should conform to the trend and direction of the development of the times. We should prominent the education of ideal and belief and the cultivation of core values. We should adhere to the peopleoriented and morality education concept, should guide university students to correct the right direction of the future.

Ideological and political work is fundamentally the work of human being. How to analyze human essence from the root and grasp the relationship between individual progress and social development is the main bottleneck restricting the innovative development of Post-90s College Students' ideological and political education. In Marx's theory, the essence of man is explained as: The essence of man is the sum of all social relations ${ }^{[3]}$. It can be summed up from the Marx doctrine: Human nature is realistic, and it is expressed through social relations. People live by society, and society is also enriched by the existence of everyone. Therefore, individual and society are interrelated and interacted. Individual development is the driving force of social progress, and society provides the necessary carrier for individual survival ${ }^{[4]}$.

\section{The Importance of Volunteer Service in the Ideological and Political Education of College Students}

In Baidu's Encyclopedia, volunteerism is described as: Any person who voluntarily contributes to the time and energy of a person to provide services for the improvement of society and social progress in the absence of any material remuneration ${ }^{[5]}$. Therefore, it is not difficult to see that the concept of volunteerism coincides with the theory of Marx doctrine on human and society.

Through carrying out voluntary service activities inside and outside college, Post-90s College Students can help others through their own efforts. They can help others grow through love to achieve their own value. According to Marx theory, individual growth will continue to promote social progress and development, and social progress and development will provide a solid foundation for individual growth. In this process of mutual influence and mutual promotion, Post-90s College Students will be deeply aware of their sense of responsibility and historical mission, and they can deepen the recognition of socialist core values. They can further recognize themselves, understand society, 
grow their talents, and increase their power and capital for their comprehensive and comprehensive development.

In recent years, voluntary service has been strongly supported by the party and the state. On the occasion of the arrival of the twenty-eighth International Volunteer Day in December 5, 2013, general secretary Xi Jinping received a cordial reply after receiving a letter from Huazhong University of Science and Technology's Ben Yu volunteer service team. In the letter, general secretary Xi Jinping fully affirmed the work of "Ben Yu volunteer service team" and the volunteer service group of contemporary college students, he encouraged them to continue to carry forward the spirit of volunteering and further contribute to serving others and contributing to the society.

In June 7, 2017, the Voluntary Service Ordinance (Draft) was examined and approved at the executive meetings of the State Council. The publishing of the ordinance will undoubtedly be a gospel to volunteer service work in China. The ordinance not only specifies the rights and obligations of volunteers, but also puts forward some concrete measures to protect the rights and obligations. So, from now on, the volunteer service work has reasons and rules to follow. The nation's attention is bound to make voluntary service become a powerful driving force in the process of promoting social progress.

\section{RESEARCH ON THE EFFECTIVE WAY OF IDEOLOGICAL EDUCATION FOR POST-90S COLLEGE STUDENTS}

\section{A. Principle of Inner Assist to Needy Students: Classify and Assist Precisely}

In college campus construction, we should regard the socialist core values as the ideological basis of campus culture construction and make full use of campus culture construction to spread the socialist core values. With this guiding ideology, we can achieve the organic combination of harmonious campus culture construction and the cultivation of socialist core values.

In this work, we are taking the assisting and helping activities in the school as the main line. We divide the grade, divide the professional and separate individuals into the specialization, refinement and humanized help. We should take out the "embroidery" effort to carry out the aid and help activities, so that the help effect is more accurate.

- To carry out various forms of activities in the form of grade and in combination with the distinctive characteristics of the Post-90s College Students in different grades. For the junior students, the importance of learning in college life is emphasized and the concept of lifelong learning runs through. By conducting activities such as "zero distance learning," "learning bullying hall", "academic guidance center" and other activities, we should encourage excellent to help students with learning difficulties. For senior students, we should focus on developing employment and further education, and we should carry out activities such as "graduate student experience exchange conference", "excellent schoolmasters face to face", "Party member service center" and so on. We can invite excellent seniors to explain and exchange common problems in postgraduate entrance examination and employment process, relieve psychological anxiety of college students, and provide valuable experience for them.

- Take different major as the unit, carry out " $1+\mathrm{N}$ " grid docking activities. The graduate students are specialized in the various classes of undergraduate students. In the course of the activities, the graduate students have a professional knowledge explanation and career planning guidance to the undergraduates. So that undergraduates can have a general understanding of their majors as early as possible, and they can realize the importance of career planning, so that they can plan for themselves as early as possible.

- Take the class as the unit, carry out the knot counterpart activity. We should fully mobilize the enthusiasm of student cadres and party members, use their bridge ties between teachers and students to carry out love and help activities. We divide the area of responsibility according to their specialties. In the area of responsibility, they can hand in hand to the students. We should give meticulous care to life, study and work, so as to help difficult students live through college life with the spirit of "keeping a good section of a canal and planting a good responsibility field".

\section{B. Out-of-school Practice: Comprehensive Mobilization and Full Participation}

The viewpoint of practice is the prime and most essential viewpoint in Marxism philosophy. For colleges and universities, practice education is a necessary part. According to the spirit of Document No. 16 of the Central Committee, the role of social practice in college students' ideological and political education cannot be ignored. Through social practice, On the one hand, college students can sharpen their own, on the other hand, they can also understand the society deeply and enhance the sense of social responsibility.

Taking the practice service activities outside the school as the main line, we should actively mobilize all the post-90s universities to participate in the voluntary service activities of different forms and pertinence. Form the situation of "everyone participates in and everyone dedicates". Using the winter vacation and summer vacation of college students, we should actively guide the Post-90s College Students to go out of school and enter the society, and they can carry out activities such as productive labor, practical teaching, public welfare dedication and volunteer service with distinct themes. Through practical activities, they can go deep into the grassroots and society, determined for human and social development and progress of services. In various practical activities, the Post-90s College Students can clearly understand the practical significance of the socialist core values. Constantly strengthen the ideals and beliefs of the 
Post-90s College Students, enhance their road confidence and theoretical confidence.

\section{Logistic Service: Perfect the Mechanism and Strengthening the Effect}

In order to stimulate the enthusiasm of participating activities, the relevant incentive mechanism is formulated and perfected.

We should make full use of modern media means to carry out propaganda and report on College Students' participation in assisting and volunteering. We should improve the satisfaction and identity of the society and the University for the Post-90s College Students' Volunteer Service.

Through the selection of outstanding student volunteers, foster advanced models, actively create a good atmosphere, further incentives for Post-90s College Students to participate in voluntary service activities, in order to improve the strength and intensity of ideological and political education of voluntary service.

Colleges and universities should strengthen the support for college students' volunteer service. We should bringing the volunteer service into the annual work plan and incorporating the ideological and political education system, the necessary support is given in terms of policies, regulations, service sites, and funds for activities. Efforts should be made to create a new situation in the ideological and political construction of college students.

\section{CONCLUSION}

The Post-90s College Students are the typical representative of the development of the times, it is an important task for today and in the future to carry out voluntary service activities according to their own distinctive features. The work related to the development of volunteer service to become a common practice in the Post-90s College Students' Ideological and political education.

\section{REFERENCES}

[1] Shao yali. Investigation and Research on the ideological situation of the post-90s college students in the network era[J]. Journal of Sichuan University of Science and Engineering (SOCIAL SCIENCE) ,2013,28(05):54-58.

[2] Shen zhuanghai, Wang Yingying. Investigation and analysis of College Students' Ideological and political education in the year of 2016- Survey based on 35 universities in China[R].2017.06.

[3] Karl Marx and Frederick Engels( The 1st volumes) [M],Beijing: People's Publishing House, 2016.7: 60.

[4] Liang Lvqi. <Study on the cultivation of volunteer service and the socialist core values of College Students> [M], Beijing: China Social Sciences Press, 2016.11: 70-72.

[5] Baidu Encyclopedia. Volunteer service [OL].[2017.08] https://baike.baidu.com/item/\%E5\%BF\%97\%E6\%84\%BF\%E6\%9C $\% 8 \mathrm{D} \% \mathrm{E} 5 \% 8 \mathrm{~A} \% \mathrm{~A} 1 / 627493$ ?fr=aladdin. 